\title{
A LEVEGŐMINŐSÉG ELŐREJELZÉSE BUDAPESTRE CAMS MODELLEKKEL
}

\author{
Varga-Balogh Adrienn (D), Leelőssy Ádám (D), Mészáros Róbert iD \\ Eötvös Loránd Tudományegyetem, Meteorológiai Tanszék \\ 1117 Budapest, Pázmány Péter sétány 1/A. \\ e-mail: vargabaloghadrienn@gmail.com, leelossyadam@gmail.com, \\ mrobi@nimbus.elte.hu
}

\section{Bevezetés}

A légszennyezés korunk egyik legnagyobb környezeti kihívása. Annak ellenére, hogy számos emisszió-csökkentési stratégia és innovatív technológia hatására Európa és hazánk levegőminősége javult (Tørseth et al., 2012), bizonyos időjárási helyzetekben és kibocsátások mellett az egészségre rendkívül káros légszennyezettségi helyzet alakulhat ki a városokban (Pascal et al., 2013). A lakosság tájékoztatása és a kibocsátók megfelelő szabályozása pontos előrejelzéseken alapulhat. Ugyanakkor a légszennyezettség mértéke számos időjárási állapothatározótól és egyéb környezeti tényezőtől függ, ezért ennek az előrejelzése igen összetett feladat.

Kutatásaink során a 2018-19-es téli időszakra a Copernicus Atmosphere Monitoring Service (CAMS) aeroszol részecske (PM10) koncentráció-előrejelzését vetettük össze az Országos Légszennyezettségi Mérőhálózat budapesti mérőállomásának adataival.

\section{CAMS modellek}

A CAMS modellek Európában egymástól függetlenül fejlesztett modellek, melyek eltérően használják a kémiát, különböző felbontásúak horizontálisan és vertikálisan is. A modellek ugyanakkor közös antropogén emissziós leltárral számolnak és a felhasznált meteorológiai előrejelzés is azonos (az ECMWF fejlesztéseként készülő IFS - Integrated Forecasting System).

1. táblázat: A 7 független CAMS modell, a modelleket fejlesztő intézetek, valamint horizontális-, illetve vertikális felbontásuk.

\begin{tabular}{|c|c|c|c|}
\hline MODELL & INTÉZET & $\begin{array}{l}\text { HORIZONTÁLIS } \\
\text { FELBONTÁS }\end{array}$ & $\begin{array}{l}\text { VERTIKÁLIS } \\
\text { FELBONTÁS }\end{array}$ \\
\hline CHIMERE & INERIS (Franciaország) & $0,1^{\circ} \times 0,1^{\circ}$ & $\begin{array}{l}9 \text { szint a felszíntől } \\
500 \mathrm{hPa} \text {-ig }\end{array}$ \\
\hline EMEP & MET Norway (Norvégia) & $0,125^{\circ} \times 0,0625^{\circ}$ & $\begin{array}{l}20 \text { szint } 100 \mathrm{hPa}-\mathrm{ig} \text {, } \\
10 \text { a határrétegben }\end{array}$ \\
\hline EURAD-IM & RIUUK (Németország) & $9 \mathrm{~km}$ & $\begin{array}{l}23 \text { szint } 100 \mathrm{hPa}-\mathrm{ig}, \\
2 \mathrm{~km} \text { alatt } 15\end{array}$ \\
\hline LOTOS-EUROS & KNMI, TNO (Hollandia) & $0,1^{\circ} \times 0,1^{\circ}$ & tszf $5 \mathrm{~km}$-ig 5 szint \\
\hline MATCH & SMHI (Svédország) & $0,1^{\circ}$ & 26 szint \\
\hline MOCAGE & $\begin{array}{l}\text { METEO-FRANCE } \\
\text { (Franciaország) }\end{array}$ & $0,1^{\circ}$ & $\begin{array}{l}47 \text { réteg } 5 \mathrm{hPa}-\mathrm{ig}, \\
2 \mathrm{~km} \text { alatt } 8 \text { réteg }\end{array}$ \\
\hline SILAM & FMI (Finnország) & $0,1^{\circ}$ & $\begin{array}{l}69-137 \text { réteg meteorológia, } \\
10 \text { réteg kémia }\end{array}$ \\
\hline
\end{tabular}


Az 1. táblázatban a CAMS (Copernicus Atmosphere Monitoring Service) független modellek fejlesztői, illetve a horizontális-, és vertikális felbontásuk látható. Az európai térségre vonatkozó elörejelzések a 7 modellel különböző felbontásban készülnek. A fenti modellek alapján készül egy ENSEMBLE elörejelzés is. Ehhez a modelleket egységesen $0,1^{\circ} \times 0,1^{\circ}$-os felbontásra interpolálják az európai domain-re (Ny.h. $25^{\circ}-$ K.h. $45^{\circ}$, É.sz. $30^{\circ}$ - É.sz. $70^{\circ}$ ), az ENSEMBLE modell pedig az egyes rácspontokra elörejelzett 7 érték mediánjaként áll elő (Marécal et al., 2015).

\section{Mérések}

A modellek levegőminőség-előrejelzéseként készült rácsponti adatokat az Országos Légszennyezettségi Mérőhálózat budapesti mérőállomásainak adataival vetettük össze. A vizsgálat során a 2018-19-es téli időszakban vizsgáltuk az aeroszol részecskék (PM10) koncentrációját.

$\mathrm{Az}$ 1. ábra a Budapest, Gilice téri (külvárosi háttér) állomás által mért értékeket, valamint az állomáshoz legközelebbi rácspontra készült modell-előrejelzéseket mutatja.

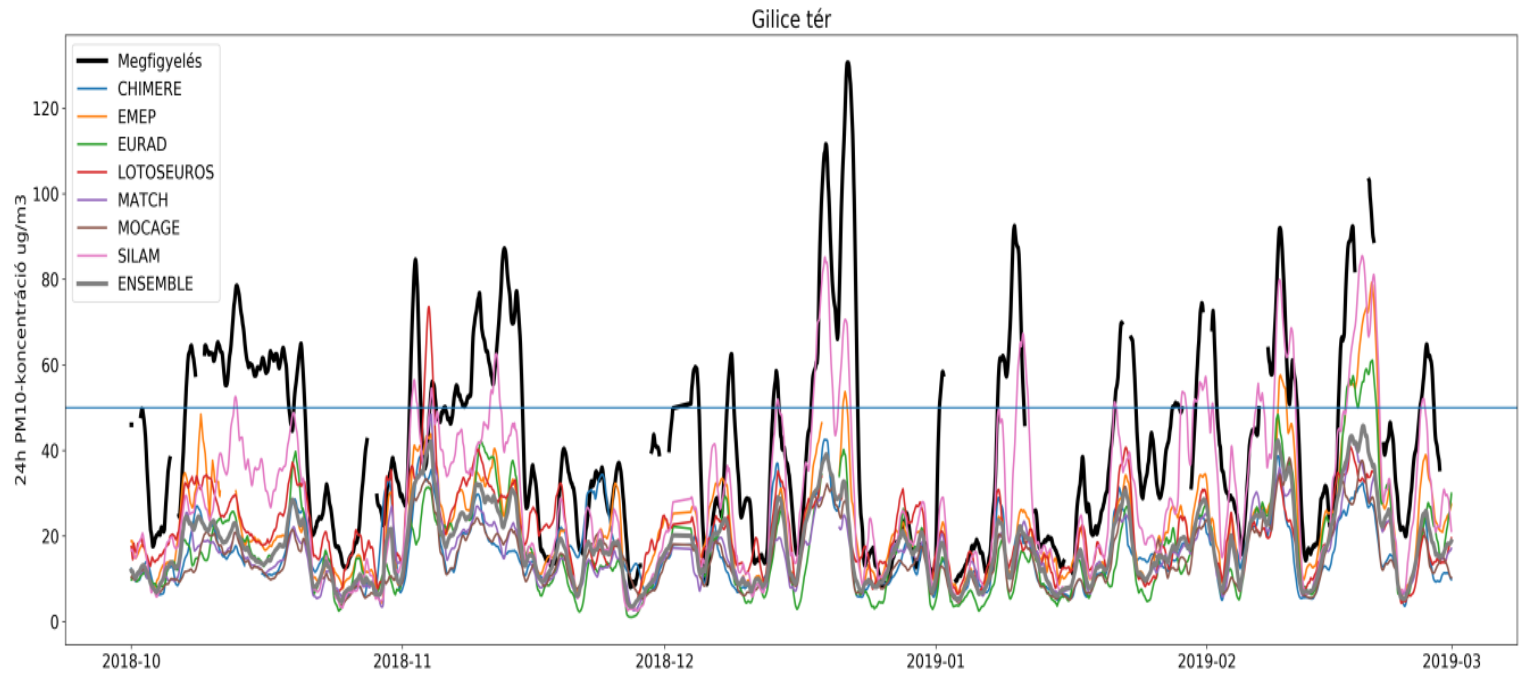

1. ábra: 2018. október - 2019 február közötti időszak PM10 koncentráció méréseinek 24 órás mozgóátlaga (feketével) a Gilice téren, illetve a modellszimulációk eredményei az állomáshoz legközelebbi rácsponton (Adatok forrása: Országos Légszennyezettségi

Mérőhálózat (OLM) és Copernicus Atmosphere Monitoring Service (CAMS)).

A 2. ábra a Budapest, Széna téri (városi közlekedési) mérőpont órás megfigyeléseit (24 órás mozgóátlagként), illetve az ehhez tartozó modell-előrejelzéseket láthatjuk.

Mindkét esetben látható, hogy a modellek jelentősen alábecsülik a ténylegesen mért koncentrációkat. Az ENSEMBLE előrejelzés általában jól követi a mért értékek menetét, azonban jelentősen kisebb értékeket jelez a megfigyelteknél. 


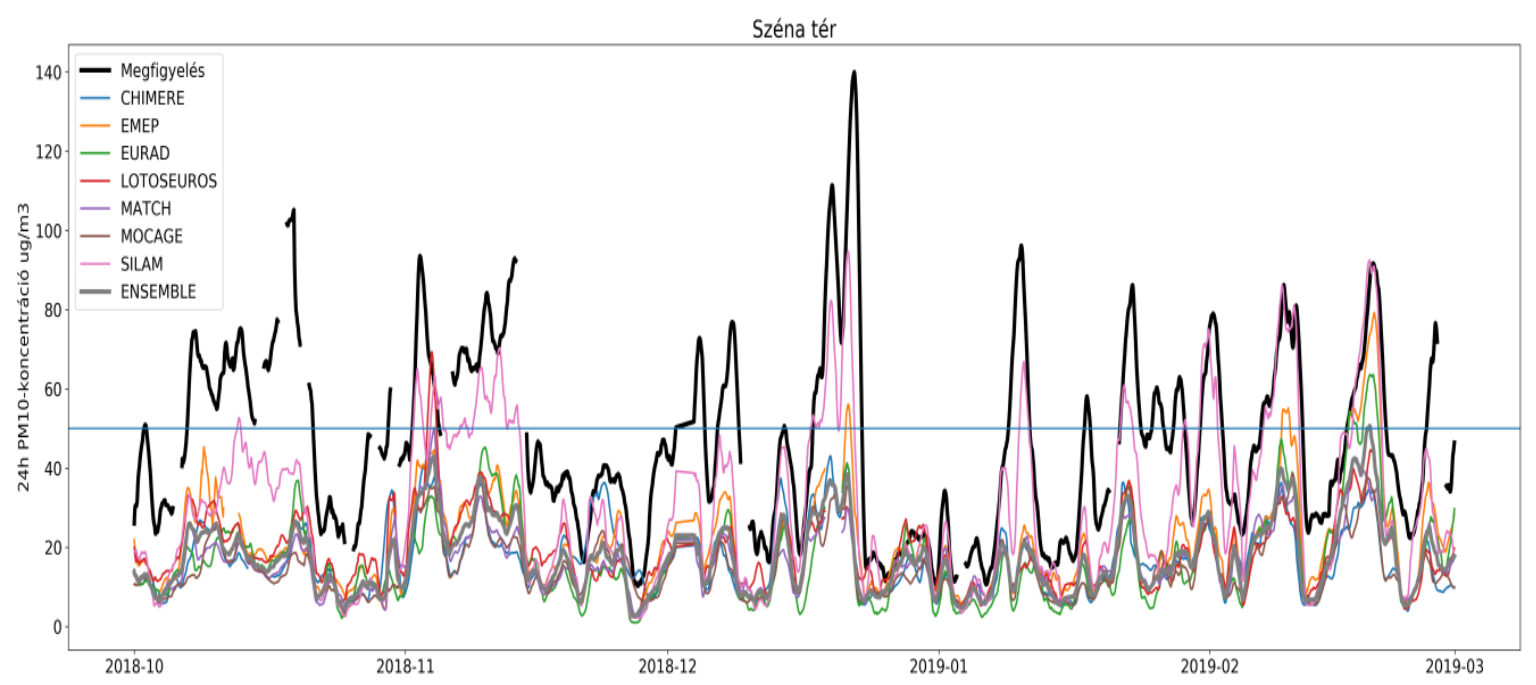

2. ábra: 2018. október - 2019 február közötti időszak PM10 koncentráció méréseinek 24 órás mozgóátlaga (feketével) a Széna téren, illetve a modellszimulációk eredményei az állomáshoz legközelebbi rácsponton (Adatok forrása: OLM és CAMS).

A 3. ábra a 2018. október - 2019. február időszakban a perzisztencia, illetve az előrejelzések beválása látható. A legtöbb modell esetén a Pearson-korreláció értéke a külvárosi háttér (Gilice téri) méröállomáson magasabb, mint a városi közlekedési (Széna téri) állomás esetén. Ez azzal magyarázható, hogy a modellek rácsponti elörejelzése nem tudja figyelembe venni a városi környezet által generált PM10-többletet, illetve a beépítettség okozta feldúsulást. A modellek közül kiemelkedő a SILAM, mely a kül- és belvárosban egyaránt a legmagasabb korrelációval jelezte előre a légszennyező anyagok koncentrációját.

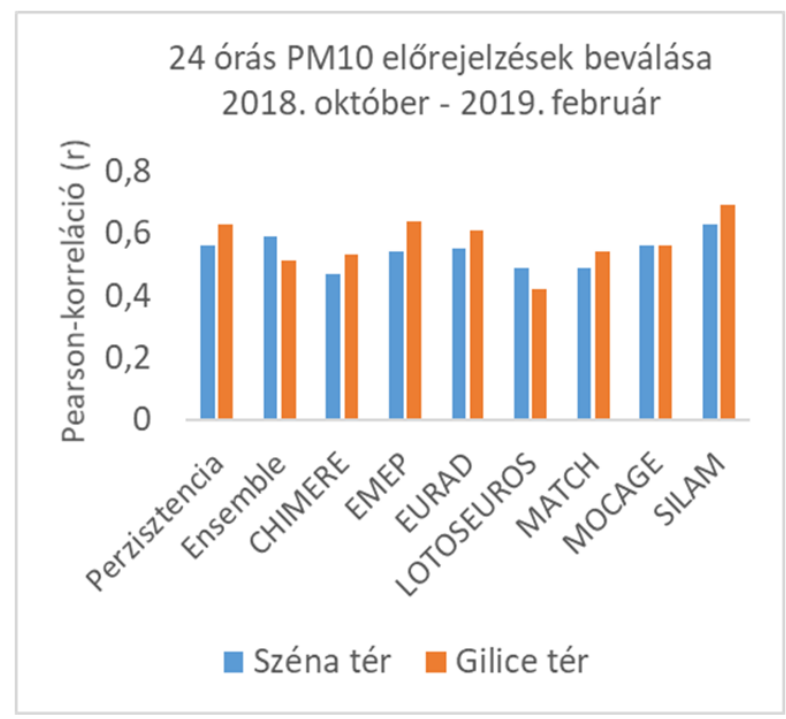

3. ábra: A PM10 koncentráció 24 órás előrejelzéseinek beválása (Pearson-korreláció) a 2018. október és 2019. február közötti időszakban az egyes modellek és a perzisztencia prognózis alapján a Széna téri (kék) és a Gilice téri (narancssárga) mérőpontokra.

A 4. ábra az egyes modellek átlagos hibáját mutatja. jól látható, hogy a modellek mind a Gilice téren, mind pedig a Széna téri mérőállomás esetén jelentősen alábecsülik a PM10 koncentrációját. A modellek közül a legkisebb átlagos hibával a SILAM jelzett előre. 


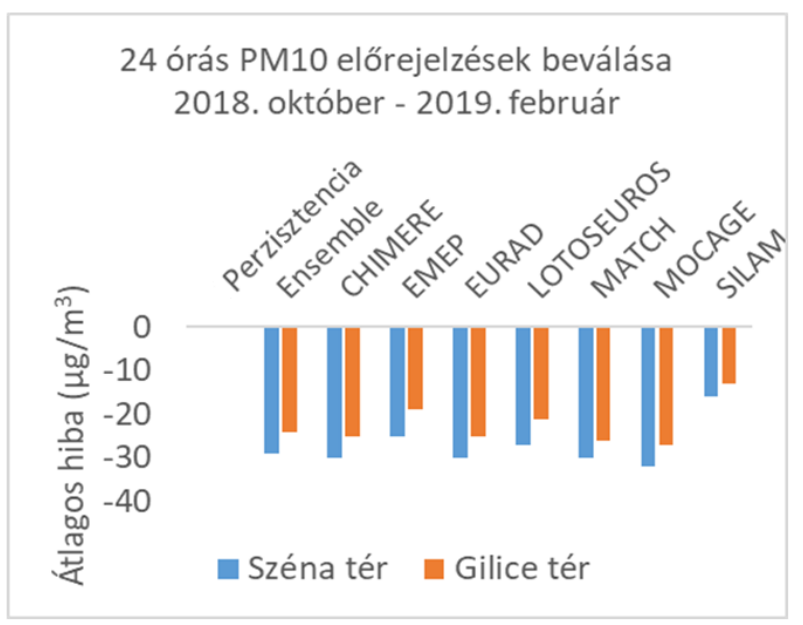

4. ábra: A PM10 koncentráció 24 órás elörejelzéseinek átlagos hibája a 2018. október és 2019. február közötti időszakban az egyes modellek és a perzisztencia prognózis alapján a Széna téri (kék) és a Gilice téri (narancssárga) méröpontokra.

A 24 órás perzisztencia-elörejelzés, a CAMS ENSEMBLE, illetve a SILAM modellek elörejelzésének validációja a 2. táblázatban látható. A korreláció szempontjából mindkét méröállomás esetén a SILAM modell előrejelzése bizonyult jobbnak, az átlagos hiba szempontjából pedig a perzisztencia. A modell érzékenysége megmutatja, hogy a szmogos $\left(50 \mu \mathrm{g} / \mathrm{m}^{3}\right.$ feletti) helyzeteket hány százalékban jelezte előre a modell. A vizsgált időintervallumban mindkét mérőállomáson az ENSEMBLE előrejelzés érzékenysége $0 \%$ volt, vagyis nem mutatott szmogos állapotot. A relevancia megadja, hogy a modell által szmogos helyzetnek becsült időpontban valóban $50 \mu \mathrm{g} / \mathrm{m}^{3}$-nél magasabb értéket mértek-e. A külvárosi mérőállomáson az ENSEMBLE, a Széna téren pedig a SILAM végzett jobban.

2. táblázat: A 24 órás perzisztencia-elörejelzés, a CAMS ENSEMBLE, illetve a SILAM modell validációja.

\begin{tabular}{|c|l|c|c|c|}
\hline \multicolumn{2}{|c|}{} & 24 h perzisztencia & CAMS ensemble & SILAM \\
\hline \multirow{4}{*}{$\begin{array}{c}\text { Gilice } \\
\text { tér }\end{array}$} & $\mathbf{r}^{2}$ & 0,26 & 0,39 & 0,47 \\
\cline { 2 - 5 } & BIAS & $-0,3 \mu \mathrm{g} / \mathrm{m}^{3}$ & $-24 \mu \mathrm{g} / \mathrm{m}^{3}$ & $-13 \mu \mathrm{g} / \mathrm{m}^{3}$ \\
\cline { 2 - 5 } & érzékenység & $59 \%$ & $0 \%$ & $38 \%$ \\
\cline { 2 - 6 } & relevancia & $60 \%$ & $100 \%$ & $79 \%$ \\
\cline { 2 - 6 } & CAQI találat & $43 \%$ & $38 \%$ & $46 \%$ \\
\hline \multirow{4}{*}{$\begin{array}{c}\text { Széna } \\
\text { tér }\end{array}$} & $\mathbf{r}^{2}$ & 0,31 & 0,35 & 0,40 \\
\cline { 2 - 6 } & BIAS & $-0,2 \mu \mathrm{g} / \mathrm{m}^{3}$ & $-29 \mu \mathrm{g} / \mathrm{m}^{3}$ & $-17 \mu \mathrm{g} / \mathrm{m}^{3}$ \\
\cline { 2 - 6 } & érzékenység & $69 \%$ & $0 \%$ & $40 \%$ \\
\cline { 2 - 6 } & relevancia & $69 \%$ & $79 \%$ & $83 \%$ \\
\cline { 2 - 6 } & CAQI találat & $45 \%$ & $26 \%$ & $39 \%$ \\
\hline
\end{tabular}

A CAQI (Community Air Quality Index) találat azt mutatja, hogy a modellek hány százalékban találják el a tényleges légszennyezettségi indexet (1. 3. táblázat). A Széna téri állomáson legtöbbször a perzisztencia-elörejelzés, a Gilice téren pedig a SILAM modell találta el a CAQI kategóriát. 
3. táblázat: Az európai légszennyezettségi index (CAQI - Community Air Quality Index) PM10-re vonatkozó kategóriái.

\begin{tabular}{|c|c|}
\hline Community Air Quality Index (CAQI) & PM10 koncentráció $\left[\boldsymbol{\mu g} / \mathbf{m}^{\mathbf{3}}\right]$ \\
\hline Nagyon alacsony & $0-25$ \\
\hline Alacsony & $25-50$ \\
\hline Közepes & $50-75$ \\
\hline Magas & $75-100$ \\
\hline Nagyon magas & $>100$ \\
\hline
\end{tabular}

\section{Összegzés}

Munkánk során a Copernicus Atmosphere Monitoring Service (CAMS) levegőminőségelőrejelző modellek PM10 elörejelzéseit vizsgáltuk Budapesten, téli időszakban. Rendelkezésünkre állt 7 egymástól független, illetve egy ezek rácspontonkénti mediánjaként előálló multi-modell ENSEMBLE előrejelzés. A vizsgálat során azt láthattuk, hogy az ENSEMBLE előrejelzés a PM10 koncentráció időbeli változásának menetét jól követte, viszont minden esetben erősen alábecsülte a ténylegesen mért értékeket. A modellek közül a SILAM modell a külvárosban jobb előrejelzést adott a 24 órás perzisztencia-előrejelzésnél is, míg a belvárosban (Széna tér) a perzisztencia bizonyult pontosabbnak, azonban a perzisztencia-elörejelzés a hirtelen változások előrejelzésére nem képes, ezért van szükség a levegőminőség-előrejelző modellek további fejlesztésére.

A városi, beépített terület összetett emissziós forrásokkal rendelkezik, amit a modellek nem tudnak pontosan figyelembe venni. A továbbiakban a modellszimulációk pontosítását kívánjuk elvégezni a mérési adatok figyelembe vételével.

Köszönetnyilvánítás: A kutatásokat a Nemzeti Kutatási, Fejlesztési és Innovációs Alap K-128805, K116506 és K-128818 pályázatai támogatták.

\section{Hivatkozások}

Marécal, V., Peuch, V.-H., Andersson, C., Andersson, S., Arteta, J., Beekmann, M., Benedictow, A., Bergström, R., Bessagnet, B., Cansado, A., Chéroux, F., Colette, A., Coman, A., Curier, R.L., Denier van der Gon, H.A.C., Drouin, A., Elbern, H., Emili, E., Engelen, R.J., Eskes, H.J., Foret, G., Friese, E., Gauss, M., Giannaros, C., Guth, J., Joly, M., Jaumouillé, E., Josse, B., Kadygrov, N., Kaiser, J.W., Krajsek, K., Kuenen, J., Kumar, U., Liora, N., Lopez, E., Malherbe, L., Martinez, I., Melas, D., Meleux, F., Menut, L., Moinat, P., Morales, T., Parmentier, J., Piacentini, A., Plu, M., Poupkou, A., Queguiner, S., Robertson, L., Rouïl, L., Schaap, M., Segers, A., Sofiev, M., Tarasson, L., Thomas, J., Timmermans, M., Valdebenito, R., van Velthoven, A., van Versendaal, P., Vira, R., Ung, $A$., 2015: A regional air quality forecasting system over Europe: the MACC-II daily ensemble production, Geosci. Model Dev., 8: 2777-2813. https://doi.org/10.5194/gmd-82777-2015

Pascal, M., Corso, M., Chanel, O., Declercq, C., Badaloni, C., Cesaroni, G., Henschel, S., Meister, K., Haluza, D., Martin-Olmedo, P., Medina, S., 2013: Assessing the public health impacts of urban air pollution in 25 European cities: Results of the Aphekom project. Science of the Total Environment, 449: 390-400. https://doi.org/10.1016/j.scitotenv.2013.01.077 
Varga-Balogh A., Leelőssy Á., Mészáros R.:

A levegőminőség előrejelzése Budapestre CAMS modellekkel

Tørseth, K., Aas, W., Breivik, K., Fjoeraa, A.M., Fiebig, M., Hjellbrekke, A.G., Lund Myhre, C., Solberg, S. and Yttri, K.E., 2012: Introduction to the European Monitoring and Evaluation Programme (EMEP) and observed atmospheric composition change during 1972-2009. Atmos. Chem. Phys., 12: 5447-5481. https://doi.org/10.5194/acp-12-5447$\underline{2012}$

\section{ORCID:}

Varga-Balogh A. (D) https://orcid.org/0000-0002-5210-5854

Leelössy Á. (D) https://orcid.org/0000-0001-9583-0127

Mészáros R. (D) https://orcid.org/0000-0002-0550-9266 